\title{
Effects of various host plants on nutritional indices and some biochemical compounds in green oak leaf roller, Tortrix viridana $L$. (Lepidoptera: Tortricidae)
}

\author{
H. Yazdanfar, ${ }^{1}$ M. Ghodskhah Daryaei, ${ }^{1}$ J. Jalali Sendi, ${ }^{2}$ H. Ghobari, ${ }^{3}$ B. Valizadeh ${ }^{2}$ \\ ${ }^{1}$ Department of Forestry, Faculty of Natural Resources, University of Guilan, Rasht; ${ }^{2}$ Department \\ of Plant Protection, Faculty of Agriculture, University of Guilan, Rasht; ${ }^{3}$ Department of Plant \\ Protection, Faculty of Agriculture, University of Kurdistan, Sanandaj, Iran
}

\begin{abstract}
The green oak leaf roller, Tortrix viridana $\mathrm{L}$., is one of the most destructive pests, causing damages to various species of oak, feeding on different host plants including Quercus infectoria Oliv, Q. branti Lindl, and $Q$. libani Oliv. Nutritional indices, activity of enzymatic and non-enzymatic compounds of T. viridana were studied under laboratory conditions. In addition, chemical components were analysed in the leaves of the three host plants. Fourth instar larvae reared on $Q$. brant $i$ showed the highest values of relative consumption rate (RCR), approximate digestibility, and consumption index $(48.73 \pm 6.22$; $90.45 \pm 1.06$ and $97.45 \pm 12.44$ respectively), while the lowest values were observed on $Q$. libani. Efficiency of conversion of ingested food in the fourth instar larvae was the highest $(3.17 \pm 0.661)$ on $Q$. libani and the lowest $(1.53 \pm 0.164)$ on $Q$. branti. The fifth instar larvae fed on $Q$. libani had the highest RCR $(15.64 \pm 2.51)$. The highest amounts of triglycerides, uric acid, glucose, protein and the lowest activity of alkaline phosphatase were observed in the fifth instar larvae reared on $Q$. libani. The leaves of $Q$. libani highlighted the highest amounts of total
\end{abstract}

Correspondence: Jalal Jalali Sendi, Department of plant protection, Faculty of Agriculture, University of Guilan, Rasht, Iran.

Tel.: +981333690817 - Fax: +981333690281 .

E-mail: jjalai@guilan.ac.ir

Key words: Tortrix viridana; nutritional efficiency; nutritional quality.

Acknowledgements: we gratefully thank Dr. Roya Khosravi, Mr. Mohamad Rahmani and specially acknowledge Dr. Kambiz Minaei and Dr. Naghi Shabanian. This research was supported by University of Guilan and in part by Kurdistan University.

Received for publication: 13 January 2015.

Revision received: 6 July 2015.

Accepted for publication: 6 July 2015.

(C) Copyright H. Yazdanfar et al., 2015

Licensee PAGEPress, Italy

Journal of Entomological and Acarological Research 2015; 47:4954

doi:10.4081/jear.2015.4954

This article is distributed under the terms of the Creative Commons Attribution Noncommercial License (by-nc 3.0) which permits any noncommercial use, distribution, and reproduction in any medium, provided the original author(s) and source are credited. nitrogen, total protein, water, potassium, magnesium and total carbohydrate. The present research suggested that the nutritional quality of the host plants have crucial effects on T. viridana larvae.

\section{Introduction}

The plant-insect interactions are a key component in elucidating host suitability for pests (Xue et al., 2010). The responses of insect herbivores to changes in host plant quality are different according food sources (Awmack \& Leather, 2002). Quality and quantity of host plants could affect growth rate and population dynamics of insects (Slansky \& Scriber, 1985; Rossiter, 1991; Ruan \& Wu, 2001).

Knowledge relating consumed food and its utilisation is useful for better comparison among different food materials, larval stages or environmental conditions. The amount of consumed food is achievable via measuring consumption and growth, since accurate determination of material needed for a diet is dependent on the amount of consumption (Ansari et al., 2012). Differences among efficiencies of food materials are exhibited through food consumption and insect growth (Andreeva, 2010; Ansari et al., 2012). The efficiency in which the taken food is digested or utilised for growth will differ not only with the maintenance requirement for energy but also with the balance of nutrients (Gordon, 1959). Study of insect nutrition is significant in providing critical information for economic exploitation and management of insects and clarifying the relationship of energy among the communities (Awmack \& Leather, 2002; Babic et al., 2008).

The green oak leaf roller, T. viridana is one of the most destructive pests causing damages to various species of the genus Quercus sp. (Hunter, 1990). Also, it is an economically important forest pest in the west of Iran (Fazeli \& Abai, 1990). T. viridana is a monophagous pest which feeds on oak leaves for almost six weeks. Larval period of T. viridana is less than one month (between 21-26 days) (Kalapanida-Kantartzi \& Glavendekic, 2002). Females lay their eggs on oak twigs in July as the overwintering stage (Hunter, 1990; Fazeli \& Abai, 1990). During mass outbreaks, the pest cause complete defoliation leading to wood weakness (Baltensweiler et al., 1977; Rubtsov \& Utkina, 2003). Some aspects of insects biology has been studied (Du Merle, 1999; Ivashov et al., 2002; Schröder \& Degen, 2008; Kapller et al., 2011). Little information is available on the effects of host plants on nutritional indices of T. viridana. So, objectives of the present research were to determine: i) food utilisation by the larvae of T. viridana on three different host plants; ii) effects of plant nutritional components on some biochemical compounds in T. viridana; and iii) the interaction between plant nutrients and host plant species on performance of the fourth and fifth instar larvae. 


\section{Materials and methods}

\section{Host plants}

Leaves of $Q$. libani, $Q$. infectoria, and $Q$. branti were prepared to be used in this study. These plants were selected being the main oak species in forests of northern Zagros in Marivan region (35 $31^{\prime} 37^{\prime \prime} \mathrm{N}$ $\left.46^{\circ} 10^{\prime} 35^{\prime \prime} \mathrm{E}\right)$ in Kurdistan province in west of Iran. Leaves were covered with compressed wet sponges to keep their humidity and refreshed daily.

\section{Insect}

Third instar larvae were collected from the host plants and were separately reared on each host plant, i.e., $Q$. branti, $Q$. infectoria and $Q$. libani. The fourth instar larvae were individually reared with their respective undamaged leave in a plastic container $(14 \times 10 \times 5 \mathrm{~cm})$. The whole plastic containers were transferred to a growth chamber at $26 \pm 2^{\circ} \mathrm{C}, 65 \pm 5 \%$ relative humidity and $16: 8 \mathrm{~L}: \mathrm{D}$. These conditions were maintained throughout larval development.

\section{Food consumption and utilisation}

Food consumption and utilisation indices were measured according to Waldbauer (1968) and Slansky \& Scriber (1985) using dry weights of each component. Newly moulted fourth instar larvae were weighed and transferred individually into plastic containers $(14 \times 10 \times 5 \mathrm{~cm})$ with a hole covered by a fine mesh net for ventilation, and provided with fresh undamaged leaves of each examined plant. The petioles of detached leaves were inserted into water-soaked cotton to maintain humidity. The larvae were checked daily and were provided with new undamaged leaves every day. Nutritional indices were determined using fourth and fifth instars since they are the most destructive stages on trees. Weight gain was measured as difference between final larval weight and weight at the beginning of the fourth instar. The weight of eaten food was calculated as the difference between the weight of newly served food and the leftovers found the next day. The following formulae were used according to Waldbauer (1968) to calculate:

- consumption index $(\mathrm{CI})=\mathrm{E} / \mathrm{A}$;

- approximate digestibility (AD)=E-F/E;

- efficiency of conversion of ingested food $(\mathrm{ECI})=\mathrm{P} / \mathrm{E}$;

- efficiency of conversion of digested food (ECD)=P/E-F;

- relative consumption rate $(\mathrm{RCR})=\mathrm{E} / \mathrm{A} * \mathrm{~T}$; and

- relative growth rate $(\mathrm{RGR})=\mathrm{P} / \mathrm{A}^{*} \mathrm{~T}$,

where:

$A=$ means dry weight of insect over unit time;

$\mathrm{E}=$ dry weight of food consumed;

$\mathrm{F}=$ dry weight of faeces produced;

$\mathrm{T}=$ duration of feeding period; and

$\mathrm{P}=$ insect dry weight gain.

Fifth instar larvae were reared on the host plants until pre-pupation and pupation. The oven dried weights of faeces and the remaining leaf fragments were acquired by drying them at $105^{\circ} \mathrm{C}$ for $24 \mathrm{~h}$. The dried materials were allowed to be cool down in a desiccator before weighing. To acquire dry weight of leaves before feeding, fresh leaves were used to investigate a regression between oven dried weights as the dependent variable and fresh weight as independent variable.

\section{Biochemical experiments}

Thirty newly emerged fifth instar larvae of $T$. viridana were killed by freezing and homogenized in phosphate buffer $20 \mathrm{mmol} \mathrm{pH} 7.1$ (1:1, $\mathrm{w} / \mathrm{v}$ ) before being centrifuged for $10 \mathrm{~min}$ at $14,000 \mathrm{~g}$. The supernatant was transferred to new tubes and stored at $-20^{\circ} \mathrm{C}$ until used. Alkaline phosphatase (EC 3.1.3.1) activity was followed as described by Mihara et al. (1988). The substrate was incubated with tissue extract for 30 min and the reaction was stopped in by adding an alkaline solution. The spectral absorbance of p-nitrophenolate was read at $310 \mathrm{~nm}$.

$\alpha$-amylase activity was assayed using the dinitrosalicylic acid (DNS) procedure (Bernfeld, 1955), using 1\% soluble starch (Merck, Darmstadt, Germany) as substrate. Ten microliters of the enzyme were incubated for $30 \mathrm{~min}$ at $35^{\circ} \mathrm{C}$ with $500 \mu \mathrm{L}$ universal buffer and $40 \mu \mathrm{L}$ soluble starch. The reaction was stopped with the addition of $100 \mu \mathrm{L}$ DNS heating in boiling water for $10 \mathrm{~min}$. DNS is a colour reagent which reacts with the reducing groups released from starch by $\alpha$-amylase action. The boiling water stops the $\alpha$-amylase activity and catalyzes the reaction between DNS and the reducing groups of starch. Absorbance was then measured at $540 \mathrm{~nm}$. One unit of $\alpha$-amylase activity was defined as the amount of enzyme required to produce $1 \mathrm{mg}$ maltose in $30 \mathrm{~min}$ at $35^{\circ} \mathrm{C}$. A blank without substrate but with $\alpha$-amylase extract and a control containing no $\alpha$-amylase extract but with substrate were measured at the same time as the reaction mixtures. All assays were performed in duplicate and each assay was repeated at least three times. A standard curve of $\alpha$-amylase absorbance against the amount of maltose released was constructed to enable the calculation of the amount of maltose released during the $\alpha$-amylase assays. Serial dilutions of maltose ( $\mathrm{Mr} 360.32 \mathrm{mg} / \mathrm{mol}$; Merck) in the universal buffer ( $\mathrm{pH}$ 6.5 ) were made to produce the following concentrations: $0.125,0.25$, $0.5,1$ and $2 \mathrm{mg} \mathrm{mL}^{-1}$. Glucose was analysed based on Siegert (1987) and total cholesterol was measured according to Richmond (1973), which involves hydrolysing cholesterol esters with cholesterol oxidase, cholesterol esterase and peroxidase. Uric acid contents in the samples were determined using uricase as described by Valovage \& Brooks (1979) at $492 \mathrm{~nm}$. Urea was measured with urease-GDH kit (Biochem. $\mathrm{Co}$, Iran) at $340 \mathrm{~nm}$ following the manufacturer's protocol.

\section{Foliar chemistry of plant materials}

Fresh leaves of $Q$. branti, $Q$. infectoria and $Q$. libani were collected from Marivan oak forest in Kurdistan. The leaves were washed by distilled water and dried at room temperature in shade. The amounts of potassium, calcium and magnesium were determined by atomic absorption techniques according to Hanlon (1992). Phosphorus was measured based on Moore (1992). Samples diluted as 20, 40, 60 and 80 $\mathrm{mg} \mathrm{P} \mathrm{L}^{-1}$ and those were incubated for at least $30 \mathrm{~min}$. Then the absorbance was read at $660 \mathrm{~nm}$ with a visible spectrophotometer. Carbohydrate was measured based on Yoshida (Yoshida et al., 1976) and total nitrogen was analyzed according to the technique in Baker and Thompson (1992). Finally, total protein was calculated as \%TP=the percent of $\mathrm{TN} \times 6.25$. Each experiment was replicated three times.

\section{Statistical analysis}

Analysis of foliar carbohydrate, water, protein, nitrogen and other mineral components levels, larval consumption rates, concentration of biochemical compounds of $T$. viridana were compared among three host plants with one-way analysis of variance (ANOVA) using SPSS 19.0 software after determination of data normality, using arcsine transformation. Post-hoc multiple comparisons were made using least significant difference. Three replicates per experiment for oak leaf analyses and biochemical compounds were considered.

\section{Results}

Results of nutritional indices in fourth and fifth instar of T. viridana are presented in Tables 1 and 2 . CI was greatest in the fourth instar larvae reared on $Q$. branti and the lowest was on $Q$. libani $[\mathrm{F}=9.09$; degree of freedom $(\mathrm{df})=2, \mathrm{P} \leq 0.01]$. AD and RCR were highest on $Q$. branti and the lowest on $Q$. libani. However, the highest and lowest values of ECI 
were on $Q$. libani $(3.17 \pm 0.661)$ and $Q$. branti $(1.53 \pm 0.164)$, respectively $(\mathrm{F}=2.835 ; \mathrm{df}=2, \mathrm{P} \leq 0.9)$. The fourth instar larvae reared on the host plants showed no significant differences on RGR and ECD.

The results presented in Table 2 showed no significant differences for all nutritional indices excluding RCR and RGR in the fifth instar larvae. RCR was the highest in the larvae reared on $Q$. libani leaves but the lowest value was obtained on $Q$. infectoria $(\mathrm{F}=5.899$; $\mathrm{df}=2, \mathrm{P} \leq 0.05)$. However, the highest and the lowest values of RGR were found on $Q$. branti $(0.81 \pm 0.03)$ and $Q$. infectoria, respectively $(0.35 \pm 0.03)(\mathrm{F}=11.4$; $\mathrm{df}=2, \mathrm{P} \leq 0.01)$.

The effects of feeding host plants on some biochemical and metabolic compounds in T. viridana are given in Table 3 . The amounts of triglyceride and Uric acid in larvae reared on $Q$. libani were significantly higher than other two treatments $(\mathrm{F}=17.794 ; \mathrm{df}=2, \mathrm{P} \leq 0.01$ and $\mathrm{F}=17.72 ; \mathrm{df}=2$, $\mathrm{P} \leq 0.01$ respectively). The amount of glucose was highest in the larvae reared on $Q$. libani, but there was no significant differences between $Q$. libani and $Q$. branti (Table 3) $(\mathrm{F}=8.57 ; \mathrm{df}=2, \mathrm{P} \leq 0.05)$. The total protein of fifth instar larvae in $Q$. libani was more than other two treatments $(\mathrm{F}=20.29 ; \mathrm{df}=2, \mathrm{P} \leq 0.01)$. The activity of alkaline phosphatase (ALP) in fifth instar larvae fed on $Q$. branti treatment was relatively more than other two treatments $(\mathrm{F}=21.23 ; \mathrm{df}=2, \mathrm{P} \leq 0.01)$.

The nutritional components of $T$. viridana on the three host plants are shown in Table 4. The results showed that the concentration of calcium was the highest in the leaves of of $Q$. branti. $(\mathrm{F}=13.849$; $\mathrm{df}=2, \mathrm{P} \leq 0.01)$. The concentrations of potassium and magnesium were the highest in the leaves of $Q$. libani. $(\mathrm{F}=15.694 ; \mathrm{df}=2, \mathrm{P} \leq 0.01 ; \mathrm{F}=4.13 ; \mathrm{df}=2, \mathrm{P} \leq 0.05)$, respectively (Table 4$)$. The highest $(6.64 \pm 0.328)$ and the lowest (4.66 \pm 0.243$)$ values of total carbohydrate were found in the leaves of $Q$. libani and $Q$. infectoria, respectively. According to Table 4, there was no difference among concentrations of phosphorous in the leaves of three host plants. The highest concentrations of total nitrogen and total protein were in the leaves of $Q$. libani $(\mathrm{F}=8.275, \mathrm{df}=2, \mathrm{P} \leq 0.05)$. The results of $\mathrm{F}$ test shows that the differences between three host plants on water content are at limit of significance $(\mathrm{F}=2.629 ; \mathrm{df}=2, \mathrm{P} \leq 0.05)$.

Table 1. Nutritional indices in the fourth instar larvae of T. viridana on different host plants.

\begin{tabular}{lcccccc} 
Host plants & CI & AD & ECI & ECD & RCR & RGR \\
Q. branti & $97.45 \pm 12.44^{\mathrm{b}}$ & $90.45 \pm 1.06^{\mathrm{b}}$ & $1.53 \pm 0.164^{\mathrm{b}}$ & $1.69 \pm 0.18^{\mathrm{b}}$ & $48.73 \pm 6.22^{\mathrm{a}}$ & $0.7 \pm 0.052^{\mathrm{a}}$ \\
Q. infectoria & $53.79 \pm 5.67^{\mathrm{a}}$ & $83.18 \pm 1.45^{\mathrm{a}}$ & $2.45 \pm 0.506^{\mathrm{ab}}$ & $2.98 \pm 0.65^{\mathrm{a}}$ & $26.89 \pm 2.83^{\mathrm{b}}$ & $0.63 \pm 0.11^{\mathrm{a}}$ \\
\hline Q. libani & $49.94 \pm 6.55^{\mathrm{a}}$ & $89.51 \pm 1.64^{\mathrm{b}}$ & $3.17 \pm 0.0661^{\mathrm{a}}$ & $3.61 \pm 0.85^{\mathrm{a}}$ & $30.39 \pm 2.12^{\mathrm{b}}$ & $0.96 \pm 0.19^{\mathrm{a}}$ \\
\hline
\end{tabular}

$\mathrm{CI}$, consumption index; $\mathrm{AD}$, approximate digestibility; ECI, efficiency of conversion of ingested food; ECD, efficiency of conversion of digested food; RCR, relative consumption rate; RGR, relative growth rate. Mean standard errors followed by the same letter within columns indicate no significant difference $(P \leq 0.05)$ by least significant difference test.

Table 2. Nutritional indices in the fifth instar larvae of T. viridana on different host plants.

\begin{tabular}{lcccccc} 
Host plants & CI & AD & ECI & BCD & RCR \\
Q. branti & $10.89 \pm 1.42^{\mathrm{a}}$ & $80.56 \pm 3.02^{\mathrm{a}}$ & $8.25 \pm 1.33^{\mathrm{a}}$ & $10.62 \pm 2.15^{\mathrm{a}}$ & $10.88 \pm 1.42^{\mathrm{ab}}$ & $0.81 \pm 0.03^{\mathrm{a}}$ \\
Q. infectoria & $14.53 \pm 1.6^{\mathrm{a}}$ & $76.97 \pm 4^{\mathrm{a}}$ & $5.06 \pm 0.78^{\mathrm{a}}$ & $6.93 \pm 1.44^{\mathrm{a}}$ & $7.27 \pm 0.8^{\mathrm{b}}$ & $0.35 \pm 0.03^{\mathrm{b}}$ \\
\hline Q. libani & $15.64 \pm 2.5^{\mathrm{a}}$ & $80.32 \pm 3.62^{\mathrm{a}}$ & $6.05 \pm 1.28^{\mathrm{a}}$ & $7.87 \pm 1.95^{\mathrm{a}}$ & $15.64 \pm 2.5^{\mathrm{a}}$ & $0.51 \pm 0.11^{\mathrm{b}}$ \\
\hline
\end{tabular}

$\mathrm{CI}$, consumption index; $\mathrm{AD}$, approximate digestibility; ECI, efficiency of conversion of ingested food; ECD, efficiency of conversion of digested food; RCR, relative consumption rate; RGR, relative growth rate. Mean standard errors followed by the same letter within columns indicate no significant difference $(\mathrm{P} \leq 0.05)$ by least significant difference test.

Table 3. Effects of host plants on some biochemical compounds of T. viridana.

\begin{tabular}{lcccccc} 
Host plants & Triglyceride & $\begin{array}{c}\text { Uric acid } \\
(\mathrm{mg} / \mathrm{dL})\end{array}$ & $\begin{array}{c}\text { Glucose } \\
(\mathrm{mg} / \mathrm{dL})\end{array}$ & $\begin{array}{c}\text { Cholesterol } \\
(\mathrm{mg} / \mathrm{dL})\end{array}$ & $\begin{array}{c}\text { Alkaline phosphatase } \\
(\text { IU/L) }\end{array}$ & $\begin{array}{c}\text { Protein } \\
(\mathrm{g} / \mathrm{dL})\end{array}$ \\
\hline Q. branti & $0.021 \pm 0.007^{\mathrm{b}}$ & $0.056 \pm 0.013^{\mathrm{b}}$ & $0.21 \pm 0.018^{\mathrm{a}}$ & $2.526 \pm 0.015^{\mathrm{a}}$ & $4926.97 \pm 575^{\mathrm{a}}$ & $34.49 \pm 1.43^{\mathrm{c}}$ \\
Q. infectoria & $0.022 \pm 0.013^{\mathrm{b}}$ & $0.07 \pm 0.026^{\mathrm{b}}$ & $0.152 \pm 0.013^{\mathrm{b}}$ & $2.517 \pm 0.005^{\mathrm{a}}$ & $4518.97 \pm 363^{\mathrm{a}}$ & $50.38 \pm 1.33^{\mathrm{b}}$ \\
\hline Q. libani & $0.178 \pm 0.034^{\mathrm{a}}$ & $0.196 \pm 0.013^{\mathrm{a}}$ & $0.226 \pm 0.005^{\mathrm{a}}$ & $2.534 \pm 0.026^{\mathrm{a}}$ & $1417.06 \pm 254^{\mathrm{b}}$ & $71.97 \pm 6.96^{\mathrm{a}}$ \\
\hline
\end{tabular}

Mean standard errors followed by the same letter within columns indicate no significant difference $(\mathrm{P} \leq 0.05)$ by least significant difference test.

Table 4. Chemical components of three host plants.

\begin{tabular}{|c|c|c|c|c|c|c|c|c|}
\hline Host plants & Phosphorous & Calcium & $\begin{array}{c}\text { Total } \\
\text { carbohydrate }\end{array}$ & Potassium & Magnesium & $\begin{array}{c}\text { Total } \\
\text { nitrogen }\end{array}$ & $\begin{array}{c}\text { Total } \\
\text { protein }\end{array}$ & Water \\
\hline Q. branti & $1.09 \pm 0.07^{\mathrm{a}}$ & $36.98 \pm 3.52^{\mathrm{b}}$ & $5.75 \pm 0.682^{\mathrm{ab}}$ & $4.72 \pm 0.218^{a}$ & $0.075 \pm 0.03^{\mathrm{a}}$ & $1.8 \pm 0.14^{\mathrm{a}}$ & $11.24 \pm 0.89$ & $0.104 \pm 0.00 g^{b}$ \\
\hline Q. infectoria & $1.31 \pm 0.07^{\mathrm{a}}$ & $31.14 \pm 1.77^{\mathrm{b}}$ & $4.66 \pm 0.243^{\mathrm{a}}$ & $5.44 \pm 0.254^{\mathrm{a}}$ & $0.103 \pm 0.019^{a b}$ & $1.91 \pm 0.12^{\mathrm{a}}$ & $11.96 \pm 0.77^{\mathrm{a}}$ & $0.129 \pm 0.012^{\mathrm{a}}$ \\
\hline Q. libani & $1.21 \pm 0.08^{\mathrm{a}}$ & $19.31 \pm 1.43^{\mathrm{a}}$ & $6.64 \pm 0.328^{b}$ & $6.57 \pm 0.233^{b}$ & $0.163 \pm 0.014^{b}$ & $2.4 \pm 0.04^{b}$ & $15.03 \pm 0.29^{b}$ & $0.164 \pm 0.02^{\mathrm{a}}$ \\
\hline
\end{tabular}

Mean standard errors followed by the same letter within columns indicate no significant difference $(\mathrm{P} \leq 0.05)$ in a least significant difference test. 


\section{Discussion and conclusions}

The quality of host plant is associated with herbivore suitability including physical attributes, allelochemicals and/or nutritional composition (Mattson \& Scriber, 1987; Hasan \& Ansari, 2010). The quality of host plant describes the component of food which includes both absolute and relative amounts of proteins, amino acids, lipids, fatty acids, carbohydrates, water, minerals and vitamins, in which positively or negatively affect the performance of herbivorous insects (Sharma et al., 1982; Samraj \& David, 1989). All these data emphasize that nitrogen content of host plants is an important limiting factor for herbivores (Zhong-Xian et al., 2007; Ansari et al., 2012). Previous studies emphasized that insects reared on plants containing the high amount of nitrogen had a significantly faster developmental time than individuals reared on the low amount of nitrogen regimes (Taylor, 1984; Morehouse \& Rutowski, 2010; Shobana et al., 2010; Roy \& Barik, 2013). Wheeler \& Halpern (1999) showed the adverse effects of low-nitrogen plants on development time, biomass, growth rates, and nitrogen assimilation rates in Samea multiplicalis Guenee (Lep.: Pyralidae) larvae. In the current study, the nitrogen content in leaves of $Q$. libani was the highest among host plants. Moreover, fifth-instar larvae reared on $Q$. libani leaves had the highest dry weight, which is probably due to the high content of nitrogen in leaves. Taylor (1984) showed that larval weights in S. multiplicalis were positively related to nitrogen content in the diet. Furthermore, Morehouse \& Rutowski (2010) investigated that the larvae reared on reduced nitrogen diets exhibited lower relative growth rate and longer developmental time. In our experiment, larvae of T. viridana reared on the host plant containing high contents of nitrogen and protein had the lowest CI but those had the higher values of RGR, ECD and ECI on the leaves of $Q$. libani. During the fourth instar, efficiencies of food (ECI, ECD) were higher on larvae fed on the leaves of $Q$. libani compared to the larvae fed on the two other host plants. The low content of water is a preventing factor if growth rate in caterpillars (Mattson \& Scriber, 1987; Shobana et al., 2010; Roy \& Barik, 2013). Our results showed that the water contents were in the order of $Q$. libani $>Q$. infectoria $>Q$. branti, probably influencing the higher relative growth rate (RGR) in the fourth instar larvae of T. viridana when fed on $Q$. libani leaves. Obvious variation was observed in food consumption and utilisation of $T$. viridana when fed on these three host plants. This response is apparently due to nutritional contents of the plant, which varied significantly in the contents of protein, carbohydrate and some minerals $(\mathrm{Ca}$, $\mathrm{P}$, and $\mathrm{Mg}$ ). This study indicated the highestvalue of RGR in T. viridana fed on $Q$. libani but the larvae reared on $Q$. infectoria showed the lowest value of RGR, which is probably due to the highest and lowest carbohydrate contents in these plants, respectively. The leaves of $Q$. libani contained the highest amount of total protein suggesting the faster growth of T. viridana. Shobana et al. (2010) and Roy \& Barik (2013) demonstrated the relationship between food efficiencies and contents of protein and carbohydrate content which are similar to our findings. However, Morehouse \& Rutowski (2010) showed that nitrogen content is a key factor in growth and development, but carbohydrate content is a less limiting factor.

Data on nutritional indices differ from fourth and fifth instar larvae. The reason might be bound to different nutritional needs of insect during growth and developmental phases (Barton Brown, 1995). Naseri et al. (2010) and Hemati et al. (2012) also reported similar results in Helicoverpa armigera (Hubner) (Lep.: Noctuidae) Moreover, several studies showed the importance of mineral contents of diet on performance of insects. For example, Clancy \& King (1993) showed that performance of Choristoneura occidentalis Obraztsov (Lep.: Tortricidae) was optimal at low magnesium and moderate phosphorus concentrations, whereas calcium had little effect. In contrast, McKinnon et al. (1999) showed that magnesium may be positively correlated with infestation of galling adelgid (Adelges tsugae Annand) (Hem.: Adelgidae). In the present study, a clear relation was observed between growth and food consumption of T. viridana on different host plants. This may be related to the mineral contents of plants. On the other hand, the highest concentrations of potassium and magnesium were found in the leaves of $Q$. libani probably had a positive effect on T. viridana performance.

The results of our study showed that the feeding of T. viridana larvae on various host plants brings significant changes in biochemical processes of larvae. ALP is a hydrolysing enzyme responsible for removing phosphate groups from many types of molecules including, proteins and alkaloids (Hasheminia et al., 2011). Toxic chemicals, on the other hand, decrease the nutrition efficiency and ALP activity (Yoshitake et al., 1966; Eguchi \& Iwamoto, 1975). Our results showed that the activity level of this enzyme is different according to the type of host plant. We observed the highest and the lowest levels in the larvae fed on $Q$. branti and $Q$. libani, respectively and the highest and lowest concentrations of triglyceride and uric acid respectively in larvae fed on $Q$. libani and $Q$. branti. The higher nutritional value bound to total nitrogen and total protein in the leaves of $Q$. libani may be an explanation.

To sum up results of the present study indicates that nutritional quality of the host plants has a significant effect on nutritional efficiency and biochemical compounds in the larvae of T. viridana. Total protein, total nitrogen, carbohydrate are essential nutrients and water is a critical component. Variations in their levels explain the observed differences in biochemical composition and consumption rate of the larvae on different host plants. These results emphasized that the suitability of host plants can be classified as follows (descending in suitability): $Q$. libani, $Q$. infectoria and $Q$. branti. The present results will be employed in future IPM programs for controlling this insect of economic importance.

\section{References}

ANDREEVA E.M., 2010 - What can nutritional indices tell us about gypsy moth larvae (Lymantria dispar L.)? - Pestic Phytomed. (Belgrade). 25: 71-77.

ANSARI M.S., HASAN F., AHMAD N., 2012 - Influence of various host plants on the consumption and utilization of food by Pieris brassicae (Linn.). - Bull. Entomol. Res. Cambridge University Press, 102: 231-237.

AWMACK C.S., LEATHER S.R., 2002 - Host plant quality and fecundity in herbivorous insects. -Annu. Rev. Entomol. 47: 817-844.

BABIC B., POISSON A., DARWISH S., LACASSE J., MERKX-JACQUES M., DESPLAND E., BEDE J.C., 2008 - Influence of dietary nutritional composition on caterpillar salivary enzyme activity. - J. Insect Physiol. 54: 286-296.

BAKER W., THOMPSON T., 1992 - Determination of total nitrogen in plant samples by Kjeldahl. In: PLANK CO (ed.), Plant analysis reference procedures for the southern region of the United States. Southern Cooperative Series Bulletin. 13-16 pp.

BALTENSWEILER W., BENZ G., BOVEY P., DELUCCHI V., 1977 Dynamics of larch bud moth populations. - Annu. Rev. Entomol. 22: 79-100.

BARTON BROWN L., 1995 - Ontogenetic changes in feeding behavior. In: CHAPMAN R.F., DE BOER G. (eds.), Regulatory mechanisms in insect feeding. - Chapman and Hall, 307-342 pp.

BERNFELD P., 1955 - $\alpha$-amylases. - Meth. Enzymol. 1: 149-151.

CLANCY K.K., KING R.M., 1993 - Defining the western spruce budworm's nutritional niche with response surface methodology. Ecology 74: 442-454.

DU MERLE P., 1999 - Egg development and diapause: ecophysiological 
and genetic basis of phenological polymorphism and adaptation to varied hosts in the green oak tortrix, Tortrix viridana L(Lepidoptera: Tortricidae). - J. Insect Physiol. 45: 599-611.

EGUCHI M., IWAMOTO A., 1975 - Changes in protease, esterase and phosphatases in the alimentary canal of the silkworm during metamorphosis. - Insect Biochem. 5: 495-507.

FAZELI M.J., ABAI M., 1990 - Green oak leaf-roller moth in Kohkiluyeh and Boyer-Ahmad Province. - Appl. Entomol. Phytopathol. 57: 1-11.

GORDON H.T., 1959 - Minimal nutritional requirements of the German roach Blattella germanica L. - Ann. N. Y. Acad. Sci. 77: 290-351.

HANLON E.A., 1992 - Determination of potassium, calcium and magnesium in plants by atomic absorption techniques. In: Plank C.0. (Ed.), Plant analysis reference procedures for the southern region of the United States. - Southern Cooperative Series Bulletin, 30-33 pp.

HASAN F., ANSARI M.S., 2010 - Effect of different cole crops on the biological parameters of Pieris brassicae (L. ) (Lepidoptera: Pieridae) under laboratory condition. - J. Crop Sci. Biotechnol. 13: 195-202.

HASHEMINIA S.M., JALALI SENDI J., TALEBI JAHROMI K.H., MOHARRAMIPOUR S., 2011 - The effects of Artemisia annua L. and Achillea millefolium L. crude leaf extracts on the toxicity, development, feeding efficiency and chemical activities of small cabbage Pieris rapae L. (Lepidoptera: Pieridae). - Pesticide Biochem. Physiol. 99: 244-249.

HEMATI S. A., NASERI B., NOURI GANBALANI G., RAFIEE DASTJERDI H., GOLIZADEH A., 2012 - Effect of different host plant on nutritional indices of the Pod Borer, Helicoverpa armigera. - J. Insect Sci. 12:1-15.

HUNTER M.D., 1990 - Differential susceptibility to variable plant phenology and its role in competition between 2 insect herbivores on oak. - Ecol. Entomol.15: 401-408.

IVASHOV A.V., BOYKO G.E., SIMCHUK A.P., 2002 - The role of host plant phenology in the development of the oak leafroller moth, (Tortrix viridana L. Lepidoptera: Tortricidae). - Forest Ecol. Manage. 157: 7-14.

KALAPANIDA-KANTARTZI M., GLAVENDEKIC M., 2002 - Observation on the appearance and the development Tortrix viridana $\mathrm{L}$. (Lepidoptera, Tortricidae). - Acta Entomol. Serbica 7: 59-65.

KAPLLER S., SCHROEDER H., SCHUELER S., 2011 - Modelling the spatial population dynamics of the green oak leaf roller (Tortrix viridana) using density dependent competitive interactions: effects of herbivore mortality and varying host-plant quality. - Ecol. Model. 222: 1293-1302.

MATTSON W.J., SCRIBER J.M., 1987 - Nutritional ecology of insect folivores of woody plants: nitrogen, water, fiber and mineral conditions. In: SLANSKY F.J.R., RODRIGUEZ J.G. (eds.), Nutritional Ecology of insects, mites, spikes and related invertebrates. -John Wiley and Sons, New York, 105-146 pp.

MCKINNON M.L., QUIRING D.T., BAUCE E., 1999 - Influence of tree growth rate, shoot size and foliar chemistry on the abundance and performance of a galling adelgid. - Funct. Ecol. 13: 859-67.

MIHARA Y., SAITO A., KOGA K., 1988 - Changes in alkaline phosphatase activity during embryogenesis. - J. Seri. Sci. Japan 52: 62-67.

MOORE K.P., 1992 - Determination of phosphorus in plant tissue by colorimetry . In: PLANK C.0. (ed.), Plant analysis reference procedures for the southern region of the United States. - Southern Cooperative Series Bulletin, 27-29 pp.

MOREHOUSE N.I., RUTOWSKI R.L., 2010 - Developmental responses to variable diet composition in a butterfly: the role of nitrogen, carbohydrates and genotype. - Oikos 119: 636-645.

NASERI B., FATHIPOUR Y., MOHARRAMIPOUR S., HOSSEININAYEH V., 2010 - Nutritional indices of the cotton bollworm, Helicoverpa armigera, on 13 soybean varieties. - J. Insect Sci. 10: 1-14.
RICHMOND W., 1973 - Preparation and properties of cholesterol oxidase from Nocardia sp. and its application to enzymatic assay of total cholesterol in serum. - Clin. Chem.19: 1350-1356.

ROSSITER M.C., 1991 - Environmentally based maternal effects - a hidden force in insect population dynamics. - Oecologica 87: 288-294.

ROY N., BARIK A., 2013 - Influence of four host-plants on feeding, growth and reproduction of Diacrisia casignetum (Lepidoptera: Arctiidae). - Entomol. Sci. 16: 112-118.

RUAN Y.M., WU K.J., 2001 - Performances of the cotton bollworm, Helicoverpa armigera on different food plants. - Acta Entomol. Bohemoslov. 44: 205-212.

RUBTSOV V.V., UTKINA I.A., 2003 - Interrelations of green oak leaf roller population and common oak: results of 30-year monitoring and mathematical modelling. In: MCMANUS M.L., LIEBHOLD A.M. (eds.), Proceedings Ecology, Survey and Management of Forest insects. - USDA Forest Service Northeastern Research Station General Technical Report NE-311, 90-97 pp.

SAMRAJ D.A., DAVID B.V., 1989 - Life table studies on the spotted bollworm, Earias vittella (Fabricius) (Lepidoptera: Noctuidae) in cotton ecosystem. - J. Bombay Nat. History Soc. 85: 637-641.

SCHRÖDER H., DEGEN B., 2008 - Spatial genetic structure in populations of the green oak leaf roller, Tortrix viridana L. (Lepidoptera Tortricidae). - Eur. J. Forest Res.127: 447-453.

SHARMA H.C., AGARWAL R.A., SINGH M., 1982 - Effect of some antibiotic compounds in cotton on post-embryonic development of spotted bollworm (Earias vittella F.) and the mechanism of resistance in Gossypium arboreum. - Proc. Indian Acad. Sci. Animal Sci. 91: 67-77.

SHOBANA K., MURUGAN A., KUMAR N., 2010 - Influence of host plants on feeding, growth and reproduction of Papilio polytes (the common mormon). - J. Insect Physiol. 56: 1065-1070.

SIEGERT K.J., 1987 - Carbohydrate metabolism in Manduca sexta during late larval development. - J. Insect Physiol. 33: 421-427.

SLANSKY F.J., SCRIBER J.M., 1985 - Food consumption and utilization. In: KERKUT G.A., GILBERT L.I. (eds.), Comprehensive insect physiology, biochemistry, and pharmacology. - Pergamon Press, 0xford, 4: $87-163$.

TAYLOR M.F.J., 1984 - The dependence of development and fecundity of Samae multiplicalis on early larvae nitrogen intake. - J. Insect Physiol. 30: 779-785.

VALOVAGE W.D., BROOKS M.A., 1979 - Uric acid quantities in the fat body of normal and aposymbiotic German cockroaches Blatella germanica, Annl. Entomol. - Soc. Am. 72: 687-689.

WALDBAUER G.P., 1968 - The consumption and utilization of food by insects. - Adv. Insect Physiol. 5: 229-288.

WHEELER G., HALPERN M., 1999 - Compensatory responses of Samea multiplicalis larvae when fed leaves of different fertilization levels of the aquatic weed Pistia stratiotes. Entomol. Exp. Appl. 92:205-16.

XUE M., PANG Y.H., WANG H.T., LI Q.L., LIU T.X., 2010 - Effects of four host plants on biology and food utilization of the cutworm, Spodoptera Litura. - J. Insect Sci. 10: 22.

YOSHIDA S., FORNO D., COCK J., GOMEZ K., 1976 - Determination of sugar and starch in plant tissue. In: YOSHIDA S. (ed.), Laboratory manual for physiological studies of rice. - Philippines: The International Rice Research Institute, 46-49 pp.

YOSHITAKE N., EGUCHI M., AKIYAMA A., 1966 - Genetic control on the alkaline phosphatase of the midgut in the silkworm. - J. Seri. Sci Jpn. 35: 1-6.

ZHONG-XIAN L., XIAO-PING Y., HEONG K. L., CUI H., 2007 - Effect of nitrogen fertilizer on herbivores and its stimulation to major. - Rice Sci. 14: 56-66. 